\title{
Produktivitas Ayam Petelur Strain Isa Brown Pada Umur 24 - 28 Minggu
}

\author{
Production Activities of Isa Brown Strain Chicken At The Age 24-28 Weeks \\ Dedy Sulaiman ${ }^{1}$, Nani Irwani ${ }^{1}$, Karunia Maghfiroh ${ }^{1}$ \\ ${ }^{1}$ Jurusan Peternakan Politeknik Negeri Lampung, \\ Jln. Soekarno Hatta No 10 Rajabasa Bandar Lampung, 35144 \\ *E-mail korespondensi: naniirwani@ polinela.ac.id
}

\begin{abstract}
Laying hens are adult hens that are specially kept for their eggs. This chicken has a high egg production capability. The purpose of this thesis is to determine the level of productivity of ISA Brown strain laying hens aged 24-28 weeks, by calculating and comparing ration consumption standards, Hen Day Production (HDP), Feed Conversion Ratio (FCR), and mortality in laying hens CV Bisco Farm Talang Jawa Village, Merbau Mataram District, South Lampung Regency. The method used in the preparation is directly involved in conducting maintenance, discussion, study literature, and direct interviews. Feed consumption is 101 grams/bird /day, daily egg production or Hen Day Production (HDP) averaged $92.77 \%$, the average FCR value was 1.89 , and the mortality rate was $0.07 \%$.
\end{abstract}

Key words : layer, egg productivity, performance

Diterima: $\quad$ Disetujui:

\section{PENDAHULUAN}

Beternak ayam petelur menjadi salah satu usaha ternak yang sangat maju. Peternakan ayam petelur banyak dijumpai di beberapa daerah Indonesia seperti di pulau Jawa dan Sumatra. Banyaknya peternakan rakyat ataupun peternakan moderen yang menjadikan ayam petelur sebagai komoditas yang menjanjikan dalam usaha peternakan. Usaha peternakan ayam petelur berperan penting dalam menyediakan kebutuhan telur masyarakat sebagai kebutuhan protein hewani. Sejalan dengan peningkatan jumlah penduduk, permintaan terhadap telur juga meningkat. Peningkatan permintaan tersebut haruslah didukung dengan peningkatan produksi telur.

Keberhasilan dari produktivitas ayam petelur ditentukan oleh beberapa faktor, seperti kualitas pullet, manajemen pemeliharaan, dan pakan. Pakan yang sesuai dengan kebutuhan ternak baik dari segi kualitas dan kuantitasnya sangat menentukan produktivitas telur yang dihasilkan. Nilai standar produktivitas ayam petelur dapat ditentukan oleh konsumsi ransum, hen day production, feed conversion ratio (FCR), dan mortalitas. Tinggi atau rendahnya pencapaian performa ayam petelur tergantung dari manajemen pemeliharaan yang diterapkan masing-masing peternak.

Permasalahan yang sering dialami peternak saat ini adalah produksi telur rendah. Tidak jarang peternak ayam petelur yang produksinya tidak mencapai puncak. Seperti yang terjadi di peternakan ayam petelur CV Bisco Farm yang terletak di Desa Talang Jawa, Kecamatan Merbau Mataram, Kabupaten Lampung Selatan. Seperti yang telah dijelaskan sebelumnya, banyak faktor yang dapat mempengaruhi keberhasilan produktivitas ayam petelur. Jika semuanya dapat terjaga dan terpenuhi dengan baik maka produktivitas ayam petelur pada masa puncak produksi dapat dioptimalkan sehingga dapat menambah 
pendapatan dan berdampak bagi kesejahteraan peternak. Tujuan tugas akhir ini untuk mengkaji produktivitas ayam petelur strain ISA Brown umur 24 - 28 minggu di CV Bisco Farm.

\title{
MATERI DAN METODE
}

\begin{abstract}
Alat dan Bahan
Alat yang digunakan antara lain: catatan recording produktivitas ayam petelur pada umur 24--28 minggu, timbangan digital, egg tray, tempat pakan dari bahan yang biasa digunakan untuk saluran air dan tempat minum dari bahan paralon yang diberi nipel sebagai saluran keluarnya air, kandang baterai berjumlah 1500 buah dengan satu kandang berisi dua ekor sehingga daya tampungnya 3000 ekor ayam.

Bahan yang digunakan adalah ransum ayam petelur, air minum, vaksin, obat-obatan, dan ayam petelur strain Isa Brown yang tercatat memiliki umur 24 - 28 minggu dengan populasi ayam keseluruhan berjumlah 2.725 ekor di peternakan ayam petelur CV Bisco Farm, Desa Talang Jawa, Kecamatan Merbau Mataram, Kabupaten Lampung Selatan, Provinsi Lampung.
\end{abstract}

\section{Metode Pelaksanaan}

Metode yang digunakan adalah dengan melakukan diskusi, study literature dan wawancara langsung mengenai produktivitas ayam petelur serta ikut membantu melakukan pemeliharaan di peternakan ayam petelur CV Bisco Farm. Pengambilan data diperoleh dari wawancara dengan manajer, kepala kandang, anak kandang, serta pegawai gudang telur, untuk memperoleh beberapa informasi mengenai peternakan ayam petelur CV Bisco Farm, manajemen pakan dan pemeliharaan secara umum, penanganan telur hingga proses distribusinya, dan konsumsi pakan.

\section{Prosedur Kerja}

Pemberian pakan dilakukan 2 kali sehar yaitu pada pagi hari pukul 06.00--07.00 WIB dan sore hari pukul 15.00--16.00 WIB. Pemberian air minum diberikan secara ad libitum atau dengan tak terbatas. Pengambilan telur dilakukan 2 kali sehari yaitu pada pagi hari pukul 10.00 WIB dan sore hari pukul 14.00 WIB. Pengambilan dilakukan dengan teliti guna memisahkan telur yang baik dengan yang pecah atau retak. Pembersihan atau sanitasi tempat pakan, paralon serta nipel air minum, dan lingkungan dilakukan setiap hari. Sementara itu untuk kegiatan rutin sanitasi seluruh kandang dilakukan pada setiap hari Jum'at yang diikuti oleh seluruh pekerja di CV Bisco Farm.

\section{Pengamatan}

Pengamatan yang dilakukan adalah mengenai produktivitas ayam petelur di CV Bisco Farm, Desa Talang Jawa, Kecamatan Merbau Mataram, Kabupaten Lampung Selatan, Provinsi Lampung. Pengambilan data digunakan untuk mengetahui performans ayam petelur di bawah ini:

\section{Konsumsi Pakan}

Konsumsi pakan yaitu jumlah pakan yang diberikan kepada ayam dalam sehari, untuk menghitungnya yaitu pakan yang diberikan $(\mathrm{kg})$ dikurangi dengan pakan sisa. Dapat dinyatakan dengan rumus:

$$
\text { Konsumsi Pakan = Jumlah pakan yang diberikan }(\mathrm{kg})-\text { Sisa pakan }(\mathrm{kg})
$$




\section{Hen Day Production (HDP)}

Hen Day Production (HDP) adalah cara menghitung produksi telur harian; perhitungannya adalah jumlah telur dibagi jumlah ayam saat itu dikali $100 \%$, biasa dihitung selama 1 minggu atau selama satu hari saja (rata-rata selama 1 minggu). Rumus untuk menghitung HDP (Hen Day Production) adalah:

\section{Feed Conversion Ratio (FCR)}

FCR adalah menghitung jumlah pakan yang dibutuhkan oleh ayam untuk menghasilkan satu kilogram berat telur, cara perhitungannya adalah jumlah pakan kumulatif yang dikonsumsi dibagi jumlah berat telur yang dihasilkan.

\section{HASIL DAN PEMBAHASAN}

\section{Konsumsi Pakan}

Konsumsi pakan yaitu jumlah pakan yang diberikan kepada ayam dalam sehari, untuk menghitungnya yaitu pakan yang diberikan dikurangi pakan sisa. Pemberian pakan di CV Bisco Farm dilakukan pagi hari pukul 06.00-07.00 serta sore hari pukul 15.00-16.00. Data pemberian pakan pada CV Bisco Farm tersaji pada Tabel 1.

Tabel 1. Data konsumsi ransum ayam petelur di CV Bisco Farm.

\begin{tabular}{cccc}
\hline $\begin{array}{c}\text { Umur } \\
(\text { Minggu })\end{array}$ & $\begin{array}{c}\text { Jumlah Ayam } \\
(\text { ekor/minggu })\end{array}$ & $\begin{array}{c}\text { Jumlah Pakan } \\
(\text { kg/hari })\end{array}$ & $\begin{array}{c}\text { Jumlah Pakan } \\
\text { (g/ekor) }\end{array}$ \\
\hline 24 & 2725 & 275 & 101 \\
25 & 2722 & 275 & 101 \\
26 & 2722 & 275 & 101 \\
27 & 2719 & 275 & 101 \\
28 & 2717 & 275 & 101 \\
\hline Rata-rata & & & 101 \\
\hline
\end{tabular}

Sumber: CV Bisco Farm (2019)

Berdasarkan Tabel 1, konsumsi ransum pada ayam petelur di CV Bisco Farm tergolong sangat baik dengan nilai 101 g/ekor/hari. Hendrix Genetics Company (2011), menyatakan bahwa konsumsi ransum ayam petelur strain ISA Brown adalah 112 g/ekor/hari, artinya pada ayam petelur di CV Bisco Farm memerlukan lebih sedikit ransum untuk memproduksi sebuah telur.

Konsumsi ransum salah satunya dipengaruhi oleh palatabilitas ternak terhadap ransum yang diberikan. Salah satu faktor yang mempengaruhi palatabilitas adalah anti nutrisi yang terkandung dalam ransum. Selain itu faktor lain yang mempengaruhi konsumsi ransum harian adalah kandungan kalori ransum, suhu lingkungan, bobot badan, bobot telur, serta aktivitas ayam (Amrullah, 2004).

Konsumsi ransum yang lebih sedikit dapat menurunkan biaya produksi yang berasal dari pakan, sehingga mengurangi pengeluaran. Namun rendahnya konsumsi ransum dapat menurunkan produksi telur harian pada ayam karena kurangnya kebutuhan nutrisi yang diperlukan untuk pembentukan telur. Kandungan nutrisi ransum yang digunakan di peternakan ayam petelur CV Bisco Farm sudah sesuai kebutuhan. Menurut Rasyaf (2008), kebutuhan akan protein ayam petelur fase layer sebesar 17-18\%. Kandungan nutrisi ransum yang digunakan di peternakan ayam petelur CV Bisco Farm disajikan pada Tabel 2. 
Tabel 2. Kandungan nutrisi ransum ayam petelur fase layer di CV Bisco Farm

\begin{tabular}{lr}
\hline Nutrisi pakan & Jumlah \\
\hline Energy metabolisme (Kkal/kg) & $2.833-2.941$ \\
Protein (\%) & $17,5-18$ \\
Serat kasar $(\%)$ & $5-7$ \\
Lemak $(\%)$ & $4,3-5$ \\
Ca $(\%)$ & $3,4-3,5$ \\
Phosphor $(\%)$ & $0,6-1$ \\
\hline
\end{tabular}

Sumber: CV Bisco Farm (2019)

\section{Hen Day Production (HDP)}

Hen day production (HDP) adalah cara menghitung produksi telur harian, perhitungannya adalah jumlah telur dibagi jumlah ayam saat itu dikali $100 \%$, yang biasa dihitung selama 1 minggu (rata-rata selama 1 minggu). Berdasarkan data recording produksi telur yang diamati di CV Bisco Farm tersaji pada Tabel 3.

Tabel 3. Data hen day production (HDP) ayam petelur di CV Bisco Farm

\begin{tabular}{cccc}
\hline $\begin{array}{c}\text { Umur } \\
\text { (Minggu) }\end{array}$ & $\begin{array}{c}\text { Jumlah Ayam } \\
\text { (ekor/minggu) }\end{array}$ & $\begin{array}{c}\text { Jumlah Telur } \\
\text { (butir/hari) }\end{array}$ & Hen Day Production (\%) \\
\hline 24 & 2725 & 2452 & 90,02 \\
25 & 2722 & 2529 & 92,89 \\
26 & 2722 & 2556 & 93,93 \\
27 & 2719 & 2548 & 93,73 \\
28 & 2717 & 2535 & 93,31 \\
\hline Rata-rata & & & 92,77 \\
\hline
\end{tabular}

Sumber: CV Bisco Farm (2019)

Berdasarkan Tabel 3, hen day production ayam petelur di CV Bisco Farm tergolong cukup baik pada umur 24-28 minggu rata-rata 92,77\%. Namun nilai tersebut belum memenuhi standar ayam petelur strain Isa-brown yang memiliki rata-rata 94,8\% pada umur 24-28 minggu (Hendrix Genetics Company, 2011).

Kualitas ransum yang buruk, nutrisinya kurang atau tidak seimbang serta ransum yang mengandung zat racun/antinutrisi dapat menyebabkan penurunan produksi telur. Demikian halnya dengan kecukupan air minum. Ayam petelur yang tidak mengkonsumsi air minum hanya selama beberapa jam, akan berhenti berproduksi telur sampai berminggu-minggu.

Kegagalan manajemen pemeliharaan ayam petelur dapat mengakibatkan penurunan jumlah produksi dan kualitas telur. Tindakan manajemen tersebut mencakup banyak hal, antara lain kurangnya pencahayaan atau tidak cukupnya intensitas cahaya dan faktor stress yang dapat menyebabkan turunnya produksi telur.

Nilai hen day production di CV Bisco Farm yang tidak memenuhi standar dipengaruhi salah satunya konsumsi ransum yang rendah. Konsumsi ransum yang rendah dapat menurunkan produksi telur harian pada ayam, karena kurangnya kebutuhan nutrisi yang diperlukan untuk pembentukan telur. Hal itulah yang menyebabkan produksi telur pada masa puncak produksi di CV Bisco Farm tidak memenuhi standar 95\% sesuai dengan pernyataan Hendrix-genetics (2006).

Berdasarkan grafik telur pada minggu ke-24 mencapai 90,02\%, pada minggu ke-25 meningkat menjadi 92,89\%, pada minggu ke-26 mencapai puncak produksi 93,93\%, kemudian mengalami sedikit penurunan pada minggu ke-27 menjadi 93,73\%, dan pada minggu ke-28 menjadi 93,31\%. 


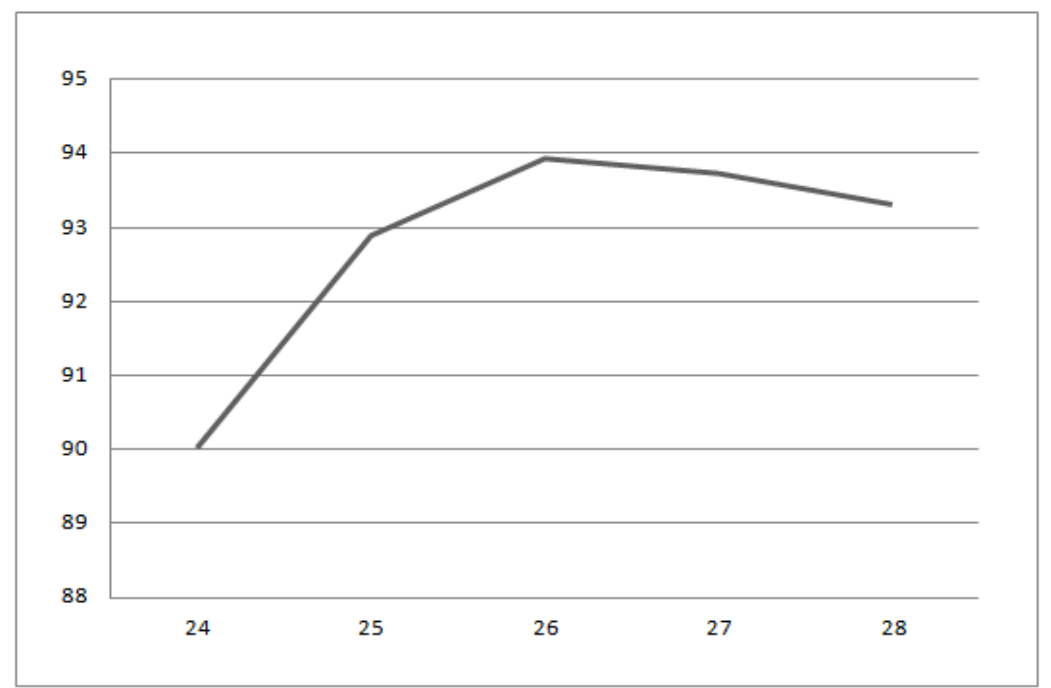

Gambar 1. Grafik hen day production umur 24 - 28 minggu di CV Bisco Farm.

\section{Feed Conversion Ratio (FCR)}

FCR adalah menghitung jumlah pakan yang dibutuhkan oleh ayam untuk menghasilkan satu kilogram berat telur, cara perhitungannya adalah jumlah pakan kumulatif yang dikonsumsi dibagi jumlah berat telur yang dihasilkan. Pada CV Bisco Farm data FCR tersaji pada Tabel 4.

Tabel 4. Data feed conversion ratio (FCR) ayam petelur di CV Bisco Farm

\begin{tabular}{ccccc}
\hline $\begin{array}{c}\text { Umur } \\
\text { (Minggu) }\end{array}$ & $\begin{array}{c}\text { Jumlah Ayam } \\
(\text { ekor/minggu })\end{array}$ & $\begin{array}{c}\text { Jumlah Pakan } \\
(\mathrm{kg} / \text { hari })\end{array}$ & $\begin{array}{c}\text { Jumlah Telur } \\
(\mathrm{kg} / \mathrm{hari})\end{array}$ & FCR \\
\hline 24 & 2725 & 275 & 139 & 1,97 \\
25 & 2722 & 275 & 147 & 1,88 \\
26 & 2722 & 275 & 147 & 1,87 \\
27 & 2719 & 275 & 149 & 1,84 \\
28 & 2717 & 275 & 146 & 1,89 \\
\hline Rata-rata & & & \\
\hline
\end{tabular}

Sumber: CV Bisco Farm (2019)

Berdasarkan Tabel 4, nilai rata-rata FCR tergolong rendah yaitu 1,89 dibandingkan dengan data strain Isa Brown memiliki rata-rata FCR 2,93 (Hendrix Genetics Company, 2011). Nilai FCR yang lebih kecil menandakan terjadinya efisiensi pakan terhadap produksi telur dan tidak terjadinya pemborosan pakan yang tentunya didukung dengan tata laksana yang baik. Nilai FCR lebih besar maka mengindikasikan terjadinya pemborosan pakan sebagai akibat tidak maksimalnya manfaat pakan terhadap produksi telur. Menurut de Rhoucey et al. (2002), faktor yang mempengaruhi konversi ransum adalah nutrisi dalam pakan, genetik, temperatur, zat aditif yang digunakan dalam ransum dan manajemen.

\section{Mortalitas}

Mortalitas adalah jumlah ayam yang mati selama pemeliharaan berlangsung dibagi jumlah ayam awal pemeliharaan dikali $100 \%$, yang biasa dihitung selama 1 minggu (rata-rata selama 1 minggu). Pada peternakan ayam petelur CV Bisco Farm data mortalitas yang didapat tersaji pada Tabel 5. 
Tabel 5. Data Mortalitas Ayam Petelur

\begin{tabular}{cccc}
\hline $\begin{array}{c}\text { Umur } \\
\text { (Minggu) }\end{array}$ & $\begin{array}{c}\text { Jumlah Ayam } \\
\text { (ekor/minggu) }\end{array}$ & $\begin{array}{c}\text { Jumlah Ayam } \\
\text { Mati }\end{array}$ & $\begin{array}{c}\text { Mortalitas } \\
(\%)\end{array}$ \\
\hline 24 & 2725 & 3 & 0,11 \\
25 & 2722 & 0 & 0,00 \\
26 & 2722 & 3 & 0,11 \\
27 & 2719 & 2 & 0,07 \\
28 & 2717 & 1 & 0,04 \\
\hline Rata-rata & & & 0,07 \\
\hline
\end{tabular}

Sumber: CV Bisco Farm (2019)

Berdasarkan Tabel 5, mortalitas pada CV Bisco Farm tergolong baik dan memenuhi standar. Hal itu karena nilai mortalitas yang rendah, standar mortalitas strain Isa Brown rata-rata 0,7\% pada umur 24-28 minggu (Hendrix Genetics Company, 2011). Menurut Rasyaf (2008) nilai mortalitas ayam petelur di Indonesia pada masa bertelur antara $0,03 \%$ hingga $0,5 \%$ per bulan. Tingkat mortalitas yang rendah ini karena sistem pemeliharaan khususnya kebersihan dan kesehatan sudah baik dan memenuhi syarat. Sistem pemeliharaan yang diterapkan dengan baik dapat menekan angka kematian pada ternak menjadi lebih rendah sehingga mengurangi angka kerugian akibat tingginya angka mortalitas.

\section{KESIMPULAN}

Berdasarkan hasil dan pembahasan dapat diperoleh kesimpulan bahwa produktivitas ayam petelur umur 24 - 28 minggu di CV Bisco Farm Desa Talang Jawa, Kecamatan Merbau Mataram, Kabupaten Lampung Selatan andalah konsumsi ransum sebesar 101 gram/ekor/hari, rata-rata hen day production (HDP) sebesar 92,77\%, rata-rata FCR sebesar 1,89, dan angka mortalitas sebesar 0,07\%.

\section{DAFTAR PUSTAKA}

Amrullah, I. K. 2004. Nutrisi Ayam Petelur. Cetakan ke-3. Bogor: Lembaga Satu Gunung Budi.

CV Bisco Farm. 2019. Catatan pemeliharaan harian. Lampung Selatan: Peternakan ayam petelur CV Bisco Farm.

De Rouchey, J.M., Tokach, M.D., Nelssen, J.L., Goodband, R.D., Dritz, S.S., Woodworth, J.C. and James, B.W. 2002. Comparison of spray- dried blood meal and blood cells in diets for nursery pigs. $J$. Anim.Sci, 80 (11), pp. 2879-2886.

Hendrix Genetic Company. 2011. Product Performance. ISA Brown, A Hendrix Genetic Company. https://eliasnutri.files.wordpress.com (7 Juli 2019).

Rasyaf, M. 2008. Panduan Beternak Ayam Petelur. Jakarta: Penebar Swadaya. 